\title{
Dehydration of Fermented Citron
}

\author{
J.R. Benero, L. E. Cancel, and A. L. Rivera ${ }^{1}$
}

INTRODUCTION

The citron (Citrus medica L.) is cultivated commercially in Puerto Rico, in the central part of the island. The producer of cured or fermented citron prepares the product by dipping the raw citron in a salt solution in which a spontaneous fermentation develops. The process is carried out in open tanks and the fermentation is continued until the citron pulp develops a certain degree of translucency. The fermented citron is washed, diced, and packed in barrels filled with salt brine. The product then is exported to the mainland and Europe.

During 1963-64 and 1964-65, 72,800 and 70,800 hundredweights of citron with a commercial value of $\$ 237,000$ and $\$ 177,000$, respectively, were exported. Producers paid transportation charges at the rate of $\$ 2.21$ per hundredweight on citron exported to Europe, and $\$ 1.30$ per hundredweight on that exported to the United States. In addition, it cost the producer $\$ 0.50$ for the transportation of each citron-filled barrel from the manufacturing plant to the shipping port.

The barrels used in the storage and transportation of the cured citron are usually bought from rum producers. The supply of these barrels is becoming scarce and the price is raising to uneconomical levels.

A group of cured-citron producers petitioned the Experiment Station's Food Technology Laboratory to conduct research on the dehydration of cured fruit for storage and marketing purposes. The Laboratory accepted this responsibility aimed at reducing transportation costs, eliminating expense of buying barrels, and lowering costs of storage of the cured product.

In a literature review, no information was found concerning dehydration of cured citron. There was, however, information on the fermentation process for citron $(1,3,4,6),{ }^{2}$ on the desalting of the cured fruit, and on the candying of this product (2).

A search was made to obtain information on the dehydration of fruits and vegetables with tissue characteristics similar to those of the citron, to establish certain criteria for its dehydration process. Products such as apples and onions with a high water content (7) have been dehydrated with temperatures of $180^{\circ}$ and $190^{\circ} \mathrm{F} .(2,8,9)$. Using the meager information

1 Associate Chemist, Food Technologist, and Assistant Chemist, respectively, Agricultural Experiment Station, Mayagüez Campus, University of Puerto Rico, Río Piedras, P.R.

2 Italic numbers in parentheses refer to Literature Cited pp. 516. 
available, dehydration experiments with citron were conducted as reported below.

\section{MATERIALS AND METHODS}

The citron used in the experiments was supplied by interested processors. The cured fruit, which came in $1 / 4-$ and $3 / 8$-inch cubes, was kept in brine until processing time.

Two different desalting procedures were assayed prior to dehydration. The first consisted of a 5-minute dip in water at room temperature, after which the citron was drained and fresh water was added, This treatment was repeated after 4 and 24 hours. For the second method the samples were treated similarly except that they were boiled gently for the first 5 minutes. This study was repeated with five different citron to water proportions by weight: $1: 1,1: 1 \frac{1}{4}, 1: 11 / 2,1: 13 / 4$ and $1: 2$. The sodium chloride concentration of the cubes was determined prior to the treatments and at each water exchange interval. Both methods were then evaluated and compared in relation to salt concentration at each interval, behavior towards dehydration, and finally as to reconstitution of the dehydrated samples.

For the overall drying studies, a model D, Proctor and Schwartz $z^{3}$ shelf dryer, equipped with perforated trays was used. The tray perforations were 0.625 inches in diameter and with approximately 51 perforations per square inch in the bottom. The ventilating fan was used at maximum speed with a draft force varying from 0.77 to 0.66 inches at the beginning and end of the drying period, respectively, for a 2-inch tray load depth, and from 0.65 to 0.60 inches for a 15-inch tray load depth. An upward air current was used to avoid blowing the dried product out of the tray.

Three experiments were conducted to study the effect of different temperatures, namely, $140^{\circ}, 160^{\circ}$ and $180^{\circ} \mathrm{F}$., on the drying of desalted citron cubes. The tray load, number of trays per cycle, and the air draft were maintained constant in the three experiments.

Another series of experiments were conducted to study the characteristics of the dehydration process. The air temperature was set at $180^{\circ} \mathrm{F}$., and the air draft at 0.75 inches. Samples for moisture determination were taken at 5-minute intervals.

The dehydrated citron cubes were evaluated in relation to their physical and organoleptic characteristics. The effect of water temperature on the rehydration of the dried product was investigated, using water at room temperature $\left(78^{\circ}-80^{\circ} \mathrm{F}\right.$.) and warm water at $130^{\circ} \mathrm{F}$.

- Trade names are used in this publication solely for the purpose of providing specific information. Mention of a trade name does not constitute a guarantee or warranty of the equipment by the Agricultural Experiment Station of the University of Puerto Rico or an endorsement over other equipment not mentioned. 
A 12-month study was conducted to determine how storage might affect the rehydration capabilities of the samples.

To determine stability of dehydrated citron, samples were exposed to atmospheres of 45 and 82 percent relative humidity. Daily moisture determinations were taken until the water content was found constant.

Finally, the candied reconstituted citron was evaluated organoleptically against a commercial sample using the $+2-2$ scale of Kramer (5) in which +2 is highly acceptable and -2 is not acceptable, and ranking them according to preference.

TABLE 1.-The effect of the fruit to water ratio, of the time of immersion in water, and of a gentle boiling for $b$ minutes in the desalting operation

\begin{tabular}{|c|c|c|c|c|c|c|}
\hline \multirow{3}{*}{$\begin{array}{l}\text { Fruit to water } \\
\text { ratio }\end{array}$} & \multicolumn{6}{|c|}{ Sodium chloride concentration treatment } \\
\hline & \multicolumn{2}{|c|}{5 minutes } & \multicolumn{2}{|c|}{4 hours } & \multicolumn{2}{|c|}{24 hours } \\
\hline & $\mathbf{A}^{1}$ & $\mathbf{B}^{1}$ & A & B & $\mathbf{A}$ & B \\
\hline & Percent & Percent & Percent & Percent & Percent & Percent \\
\hline $1: 1$ & 5.7 & 5.1 & 3.1 & 2.6 & 1.6 & 1.1 \\
\hline $1: 134$ & 5.0 & 4.5 & 2.5 & 2.2 & 1.2 & 6 \\
\hline $1: 136$ & 4.9 & 4.3 & 2.2 & 1.6 & 1.0 & 一 \\
\hline $1: 1 \% / 4$ & 5.0 & 3.9 & 2.2 & 1.6 & .7 & .6 \\
\hline $1: 2$ & 4.3 & 3.9 & 1.8 & 1.5 & .7 & .6 \\
\hline
\end{tabular}

${ }^{1} \mathrm{~A}-$ Samples soaked in water at room temperature and B, samples that were gently boiled during the first 5 minutes of soaking.

\section{RESULTS AND DISCUSSION}

The fruit to water ratio effect, the time of immersion in water, and the effect of gentle boiling in the desalting operation, are presented in table 1. Upon rehydration of the dehydrated desalted samples, it was observed that citron cubes desalted by the boiling method absorbed water giving a translucent product. It was also observed that the boiled samples were lower in salt concentration than unboiled samples at any interval of time or of any of the fruit-to-water proportions.

These results brought the decision to desalt the citron by gentle boiling for the first 5 minutes of the desalting period.

The data obtained (table 2) showed that citron dehydrated at $140^{\circ} \mathrm{F}$., $160^{\circ} \mathrm{F}$., and $180^{\circ} \mathrm{F}$., rehydrated apparently with the same characteristics. The higher temperature was considered optimum because it accomplished dehydration in the least time.

The dehydration curves in figures 1 and 2 were derived by the method suggested by Perry (8). The data upon which these curves are based was 
TABLD 2.- Effect of the drying temperature on the rehydrating characteristics of the

\begin{tabular}{c|c|c|c|c}
\multicolumn{4}{c}{ dried citron } \\
\hline Air temperature & $\begin{array}{c}\text { Initial water } \\
\text { content }\end{array}$ & $\begin{array}{c}\text { Final water } \\
\text { content }\end{array}$ & Drying time & $\begin{array}{c}\text { Water content of } \\
\text { rehydrated citron }\end{array}$ \\
\hline${ }^{\circ} R$. & Percent & Percent & Minutes & Percent \\
180 & 95.15 & 6.1 & 81 & 94.4 \\
160 & 95.15 & 7.0 & 103 & 94.1 \\
140 & 95.35 & 6.7 & 138 & 94.6 \\
\hline
\end{tabular}

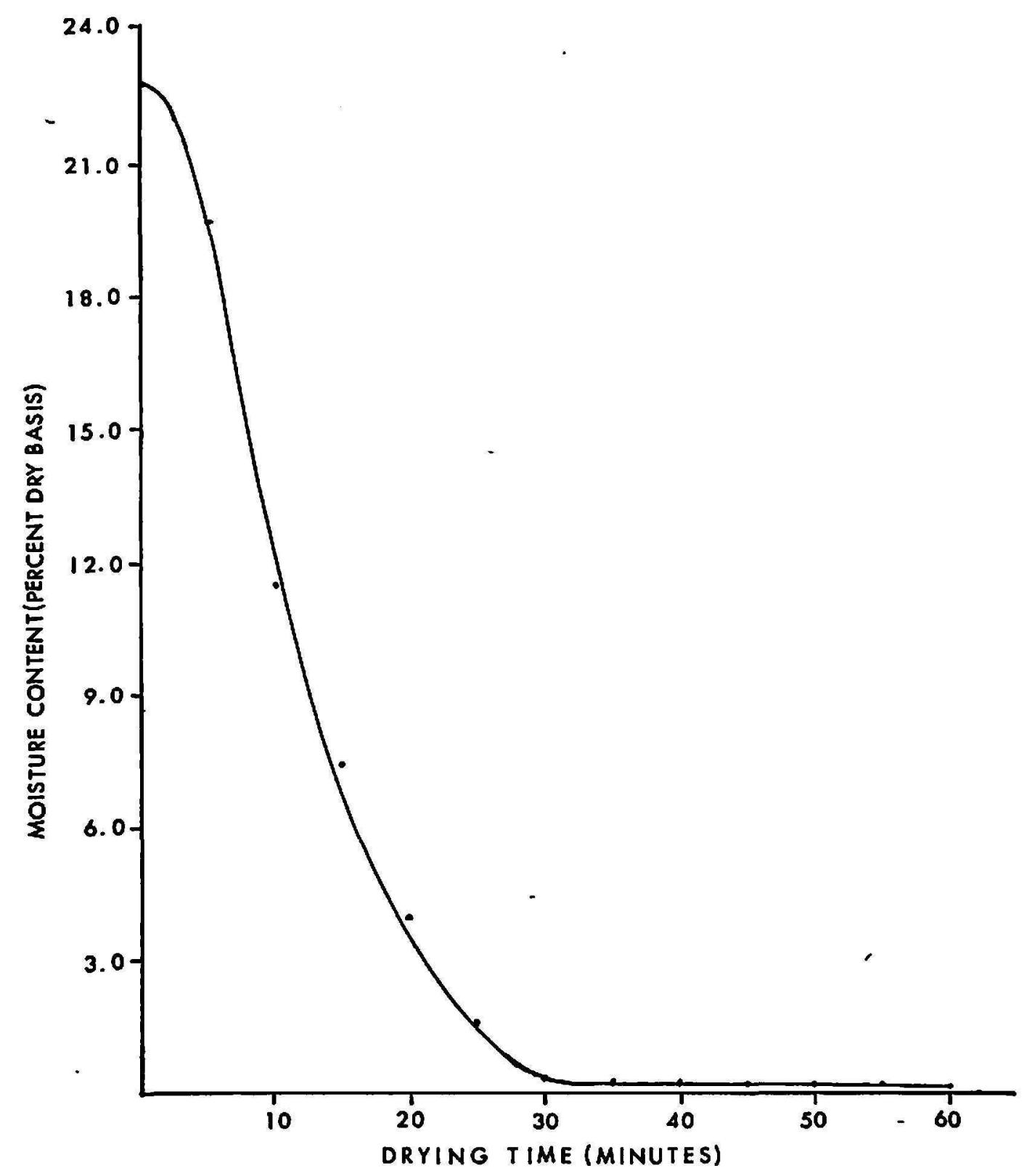

Fra. 1.-Drying rate curve for one-fourth inch cubed citron dehydrated at $180^{\circ} \mathrm{F}$. and air draft set at 0.75 inch. 
obtained by running a series of experiments in which citron, desalted by the boiling method, was dehydrated at $180^{\circ} \mathrm{F}$. and the air draft at 0.75 inches. Figure 1 shows the dehydration cycle of citron under these two factors and the data indicates that dehydration for all practical purposes occurs within the first 35 minutes.

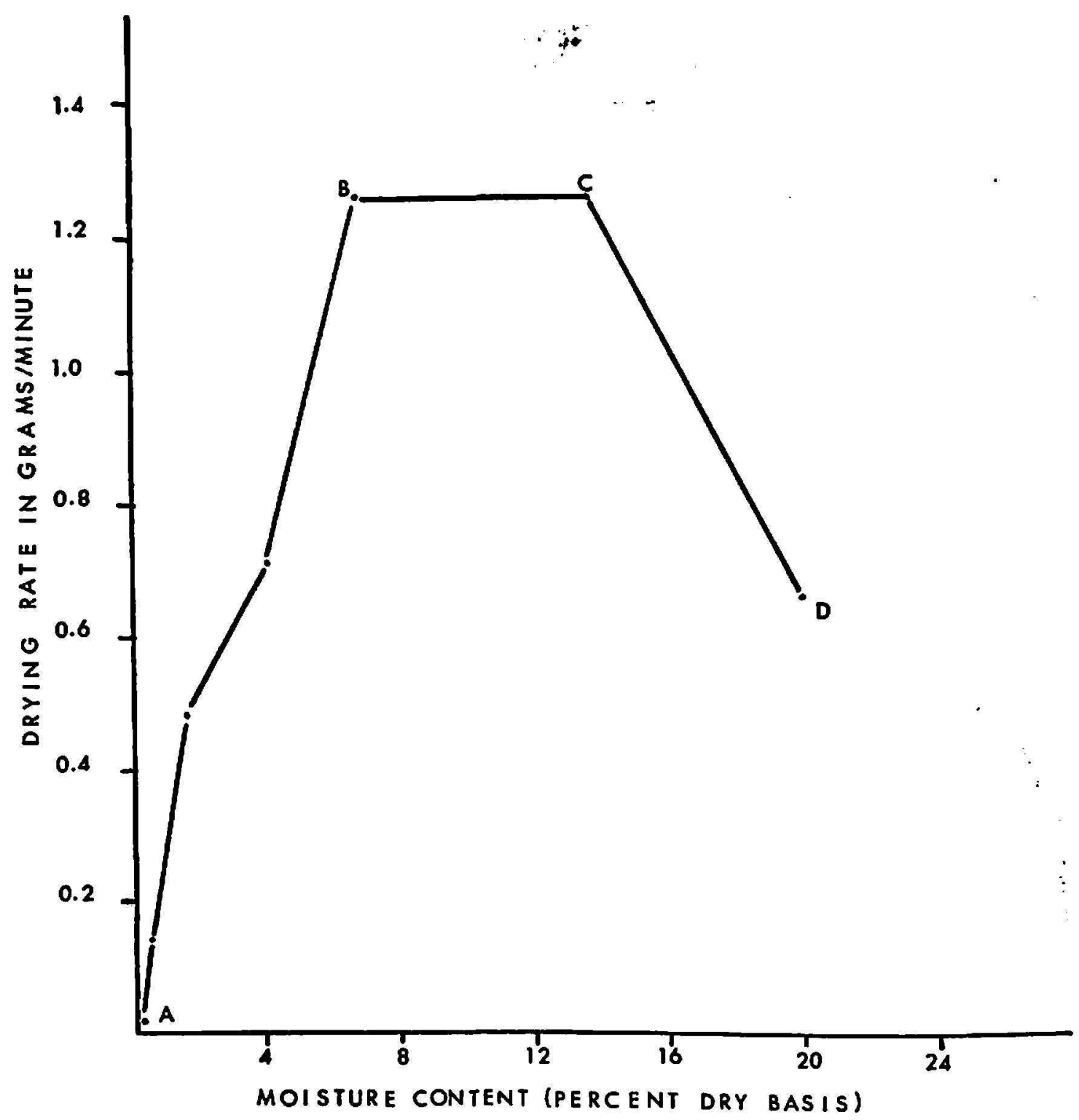

Fia. 2.-Differentiated drying rate curve for one-fourth inch cubed citron dehydrated at $180^{\circ} \mathrm{F}$. and air draft set at 0.75 inch.

Figure 2 presents the three phases of the total drying cycle. Section $\overline{\mathrm{AB}}$ of the curve represents the warming-up period, which is significant in this case because of the large amount of water evaporated. The straight line portion of the curve, $\overline{\mathrm{BC}}$, represents the constant rate evaporation period. The final portion of the curve, $\overline{\mathrm{CD}}$, is the falling rate period, typified by a continuous changing rate throughout the remainder of the drying cycle. 
Point C, where the constant rate ends and the drying rate begins to fall, is termed the critical moisture content which in this case is $7.4 \mathrm{~g}$. of water per g. of dry pulp.

All cured citron was dehydrated in the experiments to 5 to 6 percent. On dehydration a reduction in volume occurred equivalent to 90 percent of

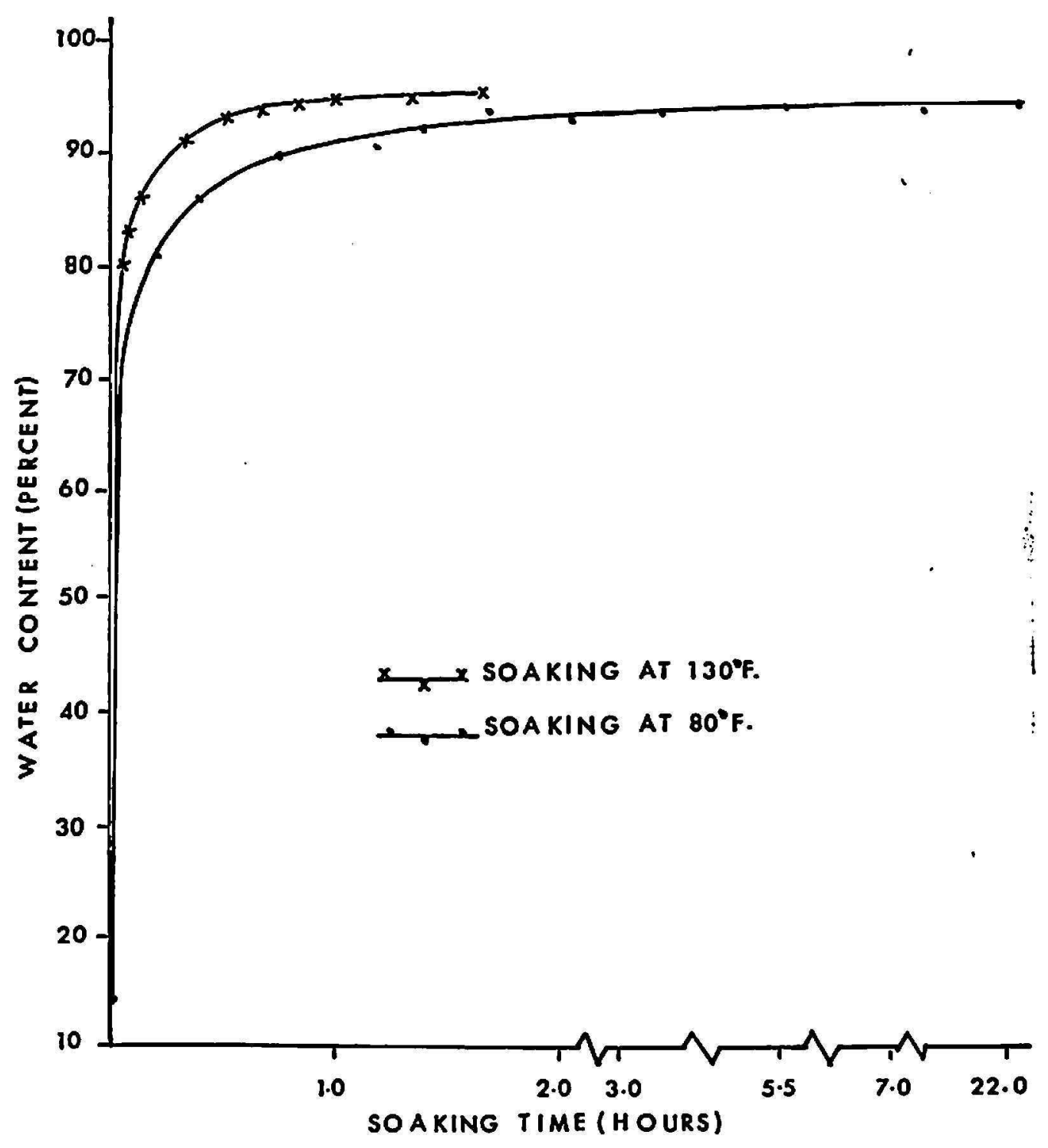

FIG. 3.-Rehydration curves of dried citron reconstituted with water at $80^{\circ}$ and $130^{\circ} \mathrm{F}$.

the original volume. The reduction in weight was 95 percent. The density of the cured citron, which has an average of $0.61 \mathrm{~g} . / \mathrm{ml}$. with a moisture content of 95 percent, went down to $0.21-0.29 \mathrm{~g} . / \mathrm{ml}$. with a moisture content of 5.0 to 6.3 percent.

The data resulting from the study on the effect of temperature of rehydration water on dehydrated citron are shown in figure 3 . Nearly total recon- 
stitution is obtained in 1 hour in water at $130^{\circ} \mathrm{F}$., while water at room temperature requires 5 to 6 hours to obtain the same results.

Dehydrated samples stabilized at a moisture content of 9.9 percent when exposed to a 45 percent relative humidity atmosphere. They stabilized at 20.1 percent under an 82 percent relative humidity. These results are presented in table 3. Dried citron packed in polyethelene plastic bags submitted to 82 percent relative humidity stabilized at 8.9 to 10 percent moisture.

Dehydrated samples were reconstituted every 3 months over a 12-month period, to study the effect of storage on the rehydrating capacity of the

TABLE 3.-Moisture equilibrium in dehydrated citron samples directly exposed to two different atmospheric conditions

\begin{tabular}{c|r|r|r|r|r|r|r}
\hline & \multirow{2}{*}{$\begin{array}{c}\text { Initial } \\
\text { water } \\
\text { content }\end{array}$} & \multicolumn{5}{|c|}{ Water content after indicated storage (days) } \\
\cline { 3 - 7 } & & 1 & 2 & 3 & 4 & 5 & 6 \\
\hline & Percenst & Percent & Percent & Percent & Percent & Percent & Percent \\
Samples at 45 percent rel- & & & & & & & \\
ative humidity & & & & & & & \\
1 & 12.4 & 10.3 & 10.7 & 10.5 & 10.1 & 10.0 & 9.9 \\
2 & 6.6 & 7.7 & 9.5 & 10.3 & 10.0 & 10.2 & 9.8 \\
3 & 6.2 & 7.2 & 9.7 & 10.3 & 10.2 & 10.2 & 10.1 \\
Samples at 82 percent rel- & & & & & & & \\
ative humidity & & & & & & & \\
1 & 13.4 & 21.2 & 22.4 & 22.4 & 20.8 & 20.4 & 20.0 \\
2 & 6.1 & 21.0 & 22.5 & 22.5 & 23.0 & 20.6 & 20.3 \\
3 & 5.4 & 21.0 & 22.8 & 22.0 & 22.7 & 20.2 & 20.0 \\
\hline
\end{tabular}

${ }^{1}$ Percent water content is calculated on a wet basis.

citron cubes. It was found that the samples reconstituted at the end of the storage period had a moisture content ranging from 93.1 to 94.1 percent whereas originally, the water content varied from 94.9 to 95.6 percent. The rehydrating capacity was thus not affected significantly by storage as shown in table 4.

Samples of reconstituted citron cubes were candied by the slow process (2). When submitted for evaluation to a testing panel, the experimental samples were significantly preferred over a commercial sample used as reference.

\section{SUMMARY}

Cured-citron was desalted by boiling gently for 5 minutes, then the water was drained off the cubes and fresh water added, in which they stood for 4 
hours. Finally, the water was again changed and the samples left standing for 20 more hours. The citron cubes were successfully dehydrated in a conventional hot air tray dryer at an air temperature of $108^{\circ} \mathrm{F}$. During dehydration, weight of the citron is reduced by 95 percent, and the volume by 90 per cent. The dehydrated product has a bulk density of $0.26 \mathrm{~g} . / \mathrm{ml}$. Dehydrated eitron has a reconstitution capacity of 98 percent for at least 12 months of storage.

The data obtained in this study indicates that cured citron can be successfully dehydrated, reconstituted, and candied, resulting in a product of good quality. These experiments show that the dehydration of cured citron will reduce costs of transportation and preservation.

TABLE 4.-Moisture equilibrium in dehydrated citron samples in storage packed in polyethylene bags

\begin{tabular}{c|c|c|c|c}
\hline \multirow{2}{*}{ Sample } & \multicolumn{4}{|c}{ Water content } \\
\cline { 2 - 5 } & ays & 180 days & 270 days & 365 days \\
\hline & Percent & Percent & Percent & Percent \\
1 & 14.5 & 11.4 & 12.0 & 12.0 \\
2 & 5.4 & 8.0 & 9.2 & 8.9 \\
3 & 5.0 & 9.6 & 11.8 & 11.0 \\
4 & 4.5 & 9.7 & 10.2 & 10.0 \\
5 & 6.3 & 9.2 & 12.4 & 10.4 \\
6 & 6.3 & 8.4 & 12.8 & 11.4 \\
7 & 6.1 & 8.2 & 9.7 & 9.6 \\
8 & 6.2 & 9.5 & 11.0 & 10.4 \\
9 & 6.3 & 10.0 & 10.0 & 10.2 \\
Average & 6.6 & 9.3 & 11.0 & 10.4 \\
\hline
\end{tabular}

\section{RESUMEN}

La cidra curada se desaló de la siguiente manera: Se hirvió por $5 \mathrm{mi}-$ nutos cambiándosele luego el agua; después de 4 horas se reemplazó el agua de nuevo, dejándose la cidra en ésta por 20 horas adicionales. La cidra curada puede deshidratarse satisfactoriamente usando un secador corriente de tablillas, a una temperatura de $180^{\circ} \mathrm{F}$. La cidra fermentada, al deshidratarse, pierde un 95 por ciento de su peso, un 90 por ciento de su volumen y su densidad baja hasta $0.26 \mathrm{~g}$. por $\mathrm{ml}$. La capacidad de rehidratación al cabo de 12 meses de almacenamiento es de un 98 por ciento.

Los datos obtenidos en este estudio demuestran que la cidra curada puede deshidratarse con éxito, reconstituirse y endulzarse, obteniéndose como resultado un producto de buena calidad. Además, se ha probado que la cidra deshidratada reducirá los costos de transporte y conservación. 


\section{LITERATURE CITED}

1. Chadefaux, S., La fermentation des cedrats, Rev. Hort. Algerie 28: 214-21, 1924.

2. Cruess, W. V., Commercial Fruit and Vegetable Products, 3rd ed., McGraw Hill Book Co., New York, N.Y., 1948.

3. Fellers, R. C., and Smith, E. G., Chemical composition and fermentation studies of citron, J. Agr. Res. 68: 859-67, 1936.

4. Hollande, A. C., et Chadefaux, S., Etude bacteriologique de la fermentation en eau de mer des cedrats des Corse destinés á la confiserie, Bull. Scient. Pharmacol. 81: 458-71, 527-39, 1924.

5. Kramer, A., Rapid method for determining significance of differences from rank sums, Food Technol. 11: 1-6, 1957.

6. McCullogs, L., Curing and preserving citron, USDA. Circular No. 18, November, 1927.

7. Nutritional Data, 3rd ed., H. J. Heinz Co., Pittsburgh, Penn., 1959.

8. Perry, J. A., Chemical Engineering Hand Book, 4th ed., McGraw Hill Book Co., New York, N.Y., 1963.

9. Von Loesecke, H. W., Drying and Dehydration of Foods. The Reinhold Publishing Co., New York, N.Y., 1955. 